\title{
Synthesis and Characterization of Some Novel Meso Functionalized Unsymmetrical Metalloporphyrins
}

\author{
PRADIP. B. GUJARATHI \\ Department of Chemistry, Shri Shivaji College Kandhar, \\ Dist Nanded-431714, Maharashtra, India \\ pradipgujarathi@gmail.com
}

Received 19 July 2016 / Accepted 3 September 2016

\begin{abstract}
New porphyrins having different functionalizations at meso-position $\left(\mathrm{A}_{3} \mathrm{~B}\right.$ type $)$ and their cobalt, nickel, copper and zinc complexes were synthesized by the reaction of unsymmetrical porphyrins with metal acetates. The synthesized metalloporphyrins were characterized by UV, IR, NMR and Mass spectra. The copper complexes of 1c and 3c were further studied by ESR spectra and magnetic measurements for complexes (1a, $\mathbf{1 c}$ and $\mathbf{3 c}$ ). Similarly the zinc complexes of $\mathbf{1 d}$ and 3d studied by fluorescence spectra
\end{abstract}

Keywords: Unsymmetrical porphyrins, Metalloporphyrins, EPR, Meso-functionalization

\section{Introduction}

Substituted porphyrins are of considerable importance owing to their use as model compounds of various tetrapyrrole pigments of nature ${ }^{1-3}$. These porphyrins are of increasing interest for their material applications ${ }^{4}$ and also for their unique physicochemical properties $^{5,6}$. 5,10,15,20-Tetraphenylporphyrin $\left(\mathrm{H}_{2} \mathrm{TPP}\right)$ and its phenyl substituted derivatives are widly explored systems due to their ease of synthesis and facile fuctionalization. Numerous reports are available on the synthesis and properties of functionalized porphyrins and metalloporphyrins ${ }^{1}$. In recent years, many functionalized meso-tetraphenylporphyrins have been employed in material applications ${ }^{4}$.

Notably, various meso-phenyl substituted MTPPs were used in the construction of supramolecular network solids ${ }^{4}$. Such solid state network is formed via intermolecular interactions arising from peripheral functional groups. Some robust network solids have been employed in shape selective sorption of amines in heterogeneous media ${ }^{7}$. Further, meso tetraphenylporphyrin derivatives substituted in the para-positions with soluble acidic, basic and neutral groups are of potential interest in medicinal chemistry because they can form chelates either with some toxic heavy metals or with gamma ray emitting radioisotopes ${ }^{8-10}$. The substituted porphyrin self assemblies have been used as versatile models for light harvesting antenna chlorophylls ${ }^{11,12}$. 
In this article, we describe the synthesis of meso substituted tetraaryl unsymmetrical metalloporphyrins $\left(\mathrm{A}_{3} \mathrm{~B}\right)$. Two common methods used for metalation of porphyrins are the acetate method and dimethyl formamide $\operatorname{method}^{13}$. But is not a general method for all porphyrins as DMF is high boiling liquid.

A third method, for metalation of porphyrins employes metal acetyalacetonate complexes as metal carrier ${ }^{13}$ this method also used high boiling solvent. In present work we used modified acetate method for preparing new metalloporphyrins low boiling solvent mixture. All the reactions are carried out by strring or heating the porphyrin wih metal acetate using chloroform/methanol solvent.

The solvent mixture employed allow the dissolution of boh reacants, $\mathrm{CHCl}_{3}$ favouring the porphyrin and $\mathrm{CH}_{3} \mathrm{OH}$ dissolves the metal acetate. Excess methanol leads to crystallisation of product. The present method is less drastic as compared to reported method.

\section{Experimental}

The unsymmetrical porphyrins (1-3) were synthesized by modified Adler method ${ }^{14}$. All reagent grade chemicals were obtained from either Aldrich (USA) or S.D. Fine Chemicals (India). The pyrrole, benzaldehyde and propionic acid were freshly distilled before use. Other chemicals were used as received. The structure of the various porphyrins and the metalloporphyrin complexes used in the present study are given in Scheme 1 \& 2 .

\section{Synthesis of unsymmetrical metalloporphyrins}

Synthesis of [5-[(4-hydroxy)phenyl]-10,15,20 tris(phenyl)porphyrinato]cobalt(II) complex $\left(\boldsymbol{C o L}^{1}\right)(\mathbf{1 a})$ :

A mixture of porphyrin (1) $(70.28 \mathrm{mg}, 0.1 \mathrm{mmol})$ in chloroform $(10 \mathrm{~mL})$ and $\mathrm{Co}(\mathrm{OAc})_{2} \cdot 4 \mathrm{H}_{2} \mathrm{O}(49.8 \mathrm{mg}, 0.2 \mathrm{mmol})$ in methanol $(10 \mathrm{~mL})$ was stirred at $60{ }^{0} \mathrm{C}$ for $1 \mathrm{~h}$. After completion of the reaction as indicated by TLC, the solvent was removed under vacuum. The residue was extracted with chloroform and washed with water. The organic layer was dried over anhydrous $\mathrm{Na}_{2} \mathrm{SO}_{4}$ and evaporation of solvent afforded pink solid compound 1a; Yield: $68.37 \mathrm{mg}, 90 \%$.

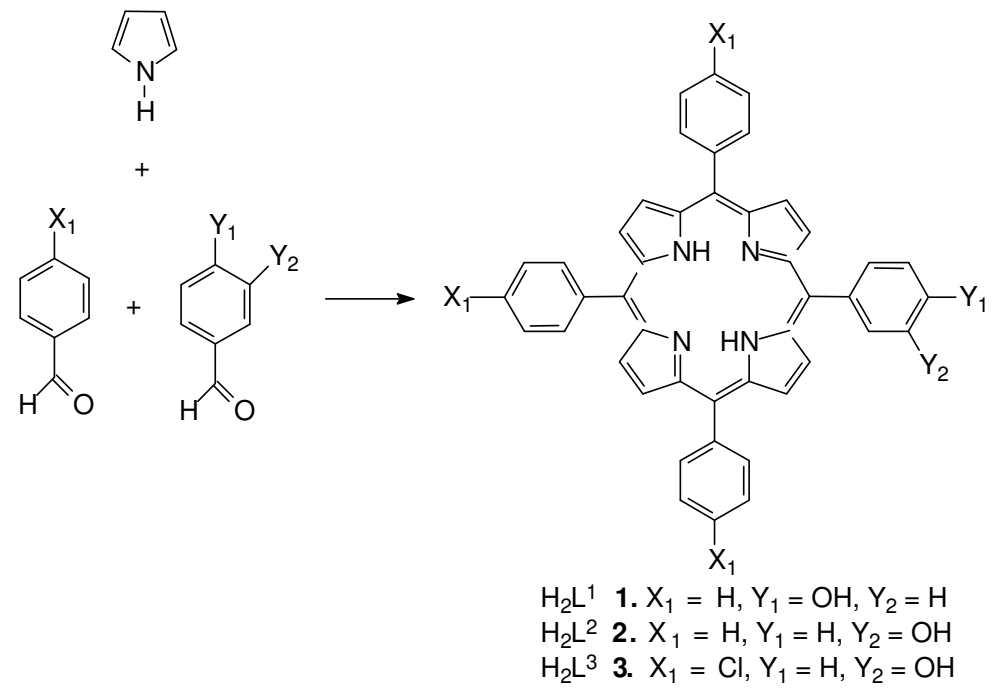

Scheme 1. Synthesis of porphyrins (1-3) 


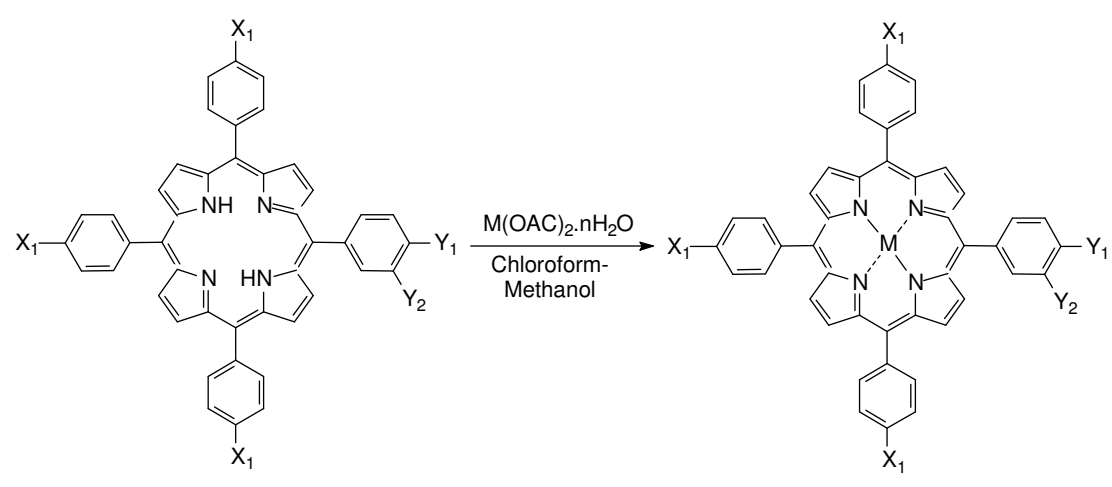

$\mathrm{H}_{2} \mathrm{~L}^{1}$ 1. $\mathrm{X}_{1}=\mathrm{H}, \mathrm{Y}_{1}=\mathrm{OH}, \mathrm{Y}_{2}=\mathrm{H}$

$\mathrm{H}_{2} \mathrm{~L}^{2}$ 2. $\mathrm{X}_{1}=\mathrm{H}, \mathrm{Y}_{1}=\mathrm{H}, \mathrm{Y}_{2}=\mathrm{OH}$

$\mathrm{ML}^{1}: \mathrm{M}=\mathrm{Co}$ (II) $\mathbf{1 a}, \mathrm{Ni}$ (II) $\mathbf{1 b}, \mathrm{Cu}$ (II) 1c, Zn (II) $\mathbf{1 d}$ $\mathrm{ML}^{2}: \mathrm{M}=\mathrm{Co}$ (II) $\mathbf{2 a}, \mathrm{Ni}$ (II) $\mathbf{2 b}, \mathrm{Cu}$ (II) $\mathbf{2 c}, \mathrm{Zn}$ (II) $\mathbf{2 d}$ $\mathrm{H}_{2} \mathrm{~L}^{3}$ 3. $\mathrm{X}_{1}=\mathrm{Cl}, \mathrm{Y}_{1}=\mathrm{H}, \mathrm{Y}_{2}=\mathrm{OH}$

$\mathrm{ML}^{3}: \mathrm{M}=\mathrm{Co}$ (II) $\mathbf{3 a}, \mathrm{Ni}$ (II) $\mathbf{3 b}, \mathrm{Cu}$ (II) $\mathbf{3 c}, \mathbf{Z n}$ (II) $\mathbf{3 d}$

Scheme 2. Synthesis of melalloporphyrins (1a-3d)

UV-Visible $\left(\lambda_{\max }\right): 235.0,412,528 \mathrm{~nm}$; IR(KBr): 704, 752.2, 798, 1004.8, 1072.3 $1170.7,1261.4,1350.1,1429.2,1566,2372.3,3649.1,3816.9 \mathrm{~cm}^{-1} ;{ }^{1} \mathbf{H}$ NMR $(300 \mathrm{MHz}$, $\mathrm{CDCl}_{3}$ ): 0.9-1.53 (br s, OH of $\left.\mathrm{H}_{2} \mathrm{O}\right), 5.2(\mathrm{~s}, 1 \mathrm{H}, \mathrm{OH}), 7.23-7.93(\mathrm{~m}, 15 \mathrm{H}, \mathrm{Ar}-\mathrm{H}), 8.22(\mathrm{~m}$, $4 \mathrm{H}$, Ar- $\mathrm{H}), 9.3(\mathrm{~m}, 8 \mathrm{H}$, pyrrole- $\mathrm{H})$ Anal. calcd. for $\mathrm{C}_{44} \mathrm{H}_{28} \mathrm{~N}_{4} \mathrm{OCo} .4 \mathrm{H}_{2} \mathrm{O}: \mathrm{C}, 69.56 \% ; \mathrm{H}$, $4.77 \%$; N, 7.37\% Found:C, 69.40\%, H, 4.32\%; N, 7.0\%.

Synthesis of [5-[(4-hydroxy)phenyl]-10,15,20-tris(phenyl)porphyrinato]nickel(II) complex $\left(\mathrm{NiL}^{1}\right)(\mathbf{1 b})$

A mixture of porphyrin (1) $(70.28 \mathrm{mg}, 0.1 \mathrm{mmol})$ in chloroform $(10 \mathrm{~mL})$ and $\mathrm{Ni}(\mathrm{OAc})_{2} .4 \mathrm{H}_{2} \mathrm{O}(99.544 \mathrm{mg}, 0.4 \mathrm{mmol})$ in methanol $(10 \mathrm{~mL})$ was stirred at $60{ }^{0} \mathrm{C}$ for $6 \mathrm{~h}$. After completion of reaction as indicated by TLC, the solvent was removed and residue washed with water, extracted with chloroform and organic layer was dried over anhydrous $\mathrm{Na}_{2} \mathrm{SO}_{4}$. After evaporation of solvent under reduced pressure, the residue was purified by column chromatography ( silica gel, 60-120 mesh, chloroform: pet ether $=8: 2$ ) to afford orange red solid compound 1b; yield: $60.76 \mathrm{mg}, 80 \%$.

UV-Visible $\left(\lambda_{\max }\right): 410.50,522,590,649 \mathrm{~nm}$; IR(KBr):796.5, 1006.8, 1172.6, 1261.4, 1353.9, 1425.3, 1510.2, 1560.3, 2354.9, 3381.0, $3649.1 \mathrm{~cm}^{-1} ;{ }^{\mathbf{1}} \mathbf{H}$ NMR $\left(300 \mathrm{MHz}, \mathrm{CDCl}_{3}\right)$ : 1.25-1.56 (br s, OH of $\left.\mathrm{H}_{2} \mathrm{O}\right), 5.2(\mathrm{~s}, 1 \mathrm{H}, \mathrm{OH}), 7.23-7.6(\mathrm{~m}, 15 \mathrm{H}, \mathrm{Ar}-\mathrm{H}), 8.21$ (m, 4H, Ar-H), $8.84(\mathrm{~m}, 8 \mathrm{H}$, pyrrole- $\mathrm{H})$ Anal. calcd. for $\mathrm{C}_{44} \mathrm{H}_{28} \mathrm{~N}_{4} \mathrm{ONi} .4 \mathrm{H}_{2} \mathrm{O}: \mathrm{C}, 69.58 \% ; \mathrm{H}, 4.77 \%$; , 7.37\% Found:C, $69.48 \%, \mathrm{H}, 4.52 \%$; N, 7.21\%.

Synthesis of [5-[(4-hydroxy) phenyl] 10,15,20-tris(phenyl)porphyrinato]copper(II) complex $\left(C u L^{1}\right)(\mathbf{1 c})$

A mixture of porphyrin $(\mathbf{1})(70.28 \mathrm{mg}, 0.1 \mathrm{mmol})$ in chloroform $(10 \mathrm{~mL})$ and $\mathrm{Cu}(\mathrm{OAc})_{2} \cdot \mathrm{H}_{2} \mathrm{O}$ $(39.92 \mathrm{mg}, 0.2 \mathrm{mmo})$ in methanol $(10 \mathrm{~mL})$ was stirred for $1 \mathrm{~h}$ at $60{ }^{\circ} \mathrm{C}$. After completion of metalation as indicated by TLC, the solvent was removed under reduced pressure and residue was washed with water to remove excess metal acetate and it was extracted with chloroform. Organic layer was dried over anhydrous $\mathrm{Na}_{2} \mathrm{SO}_{4}$ and after evaporation of solvent afforded pink solid compound 1c; yield: $68.78 \mathrm{mg}, 90 \%$.

UV-Visible $\left(\lambda_{\max }\right): 413,540,574,617 \mathrm{~nm}$; IR (KBr) : 705.9, 750.3, 798.5, 1001.0, $1072.3,1170.7,1261.4,1344.3,1440,1510.2,1600.8,2372.3,3683.8 \mathrm{~cm}^{-1}$; Far IR : 146.5, 162.8, 218.0, 262.4, $272.5 \mathrm{~cm}^{-1}$; Mass (TOF MSES + 2.14 e3) $\mathrm{m} / z: 693.4374\left(\mathrm{M}^{+}\right)$; 
${ }^{1} \mathbf{H}-\mathbf{N M R}\left(300 \mathrm{MHz}, \mathrm{CDCl}_{3}\right):$ 1.25-1.58 ( br s, -OH, of $\mathrm{H}_{2} \mathrm{O}$ ), 5.05 (s, 1H, OH), 7.25-7.64 (m, $15 \mathrm{H}, \mathrm{Ar}-\mathrm{H}), 7.92(\mathrm{~m}, 4 \mathrm{H}, \mathrm{Ar}-\mathrm{H}), 8.95\left(\mathrm{~m}, 8 \mathrm{H}\right.$, pyrrole-H) Anal. calcd. for $\mathrm{C}_{44} \mathrm{H}_{28} \mathrm{~N}_{4} \mathrm{OCu} .4 \mathrm{H}_{2} \mathrm{O}$ : C, 69.14\%; H, 4.74\%; N, 7.33\% Found : C, 69.0\%, H, 4.42\%; N, 7.10\%.

Synthesis of [5-[(4-hydroxy) phenyl)]-10,15,20-tris(phenyl)porphyrinato] zinc(II) complex $\left(\mathbf{Z n L}^{1}\right)(\mathbf{l d})$

A mixture of porphyrin (1) $(70.2816 \mathrm{mg}, 0.1 \mathrm{mmol})$ in chloroform $(10 \mathrm{~mL})$ and $\mathrm{Zn}(\mathrm{OAc})_{2} .2 \mathrm{H}_{2} \mathrm{O}(43.8 \mathrm{mg}, 0.2 \mathrm{mmol})$ in methanol $(5 \mathrm{~mL})$ was stirred at room temperature for $30 \mathrm{~min}$. After completion of metalation as indicated by TLC (silica gel 60-120 mesh, chloroform: pet ether $=7: 3$ ) the solvent was removed under pressure. The residue was washed with water and it was extracted with chloroform.

Organic layer was dried over anhydrous $\mathrm{Na}_{2} \mathrm{SO}_{4}$ and removal of solvent under reduced pressure furnished a purple solid compound 1d; yield : $65.11 \mathrm{mg}, 80 \% \mathrm{UV}$-Visible $\left(\lambda_{\max }\right)$ : 250, 311, 416, 553, 595, 621, 771.50 nm; IR (KBr) : 704.0, 750.3 798.5, 999.1, 1068.5, 1170.7, 1207.4, 1259.4, 1338.5, 1487.0, 1593.1, 2374.2, 3053.1, $3681.9 \mathrm{~cm}^{-1}$; Far IR : 190.0, 237.5, 263.2, 271.7, $287.3 \mathrm{~cm}^{-1}$; Mass (TOF MSES + 4.23 e3) $\mathrm{m} / \mathrm{z}: 694\left(\mathbf{M}^{+}\right) ;{ }^{1} \mathbf{H}$ NMR (300 $\mathrm{MHz}, \mathrm{CDCl}_{3}$ ) : $1.25-1.51$ (br s, $-\mathrm{OH}$, of $\mathrm{H}_{2} \mathrm{O}$ ), $5.2(\mathrm{~s}, 1 \mathrm{H}, \mathrm{OH}) 7.2-7.7$ (m, 15H, Ar-H), $8.2(\mathrm{~m}, 4 \mathrm{H}, \mathrm{Ar}-\mathrm{H}), 8.94\left(\mathrm{~m}, 8 \mathrm{H}\right.$, pyrrole-H) Anal. calcd. for $\mathrm{C}_{44} \mathrm{H}_{28} \mathrm{~N}_{4} \mathrm{OZn} .4 \mathrm{H}_{2} \mathrm{O}: \mathrm{C}, 68.97 \%$; $\mathrm{H}, 4.73 \%$; N, 7.31\% Found : C, 69.72\%; H, 4.52\%; N, 6.90\%.

Synthesis of [5-[(3-hydroxy) phenyl)]-10,15,20-tris(phenyl)porphyrinato]cobalt(II) complex $\left(\boldsymbol{C o L}^{2}\right)(2 a)$

A mixture of porphyrin (2) (70.2816 mg, $0.1 \mathrm{mmol})$ in chloroform $(10 \mathrm{~mL})$ and $\mathrm{Co}(\mathrm{OAc})_{2} \cdot 4 \mathrm{H}_{2} \mathrm{O}(49.8 \mathrm{mg}, 0.2 \mathrm{mmol})$ in methanol $(10 \mathrm{~mL})$ was stirred for $3 \mathrm{~h}$. After completion of metal insertion, reaction as indicated by TLC, the solvent was evaporated. Then the residue was chromatographed (silica gel 60-120 mesh, chloroform: pet ether $=$ 9:1). The second band was collected and after evaporation of solvent furnished orange pink solid compound 2a; yield: $64.57 \mathrm{mg}, 85 \%$.

UV-Visible $\left(\lambda_{\max }\right): 410.50,528.50 \mathrm{~nm} ; \mathbf{I R}(\mathrm{KBr}): 705.9,752.2,794.6,881.4,939.3$, 1002.9, 1074.3, 1170.7, 1284.5, 1350.1, 1444.6, 1595.0, 1739.7, 2923.9, 3024.2, 3055.0, $3417.6 \mathrm{~cm}^{-1}$; Far IR : 151.1, 316.8, $464.6 \mathrm{~cm}^{-1}$; Mass (TOF MSES + 337) $\mathrm{m} / \mathrm{z}: 687.32$; ${ }^{1}$ H-NMR $\left(300 \mathrm{MHz},\left(\mathrm{CDCl}_{3}\right): 0.9-1.55\left(\mathrm{br} \mathrm{s},-\mathrm{OH}\right.\right.$ of $\left.\mathrm{H}_{2} \mathrm{O}\right), 5.0(\mathrm{~s}, 1 \mathrm{H}, \mathrm{OH}), 7.20-7.8(\mathrm{~m}$, $15 \mathrm{H}, \quad \mathrm{Ar}-\mathrm{H}), \quad 8.20(\mathrm{~m}, \quad 4 \mathrm{H}, \quad \mathrm{Ar}-\mathrm{H}), \quad 8.90(\mathrm{~m}, \quad 8 \mathrm{H}$, pyrrole-H) Anal. calcd. for $\mathrm{C}_{44} \mathrm{H}_{28} \mathrm{~N}_{4} \mathrm{OCo} .4 \mathrm{H}_{2} \mathrm{O}: \mathrm{C}, 69.56 \% ; \mathrm{H}, 4.77 \%$; N, 7.37\% Found : C, 69.0\%; H, 4.52\%; N, 7.0\%.

Synthesis of [5[(3-hydroxy) phenyl)]-10,15,20-tris(phenyl)porphyrinato]nickel(II) complex $\left(\mathrm{NiL}^{2}\right)(\mathbf{2 b})$

A mixture of porphyrin (2) $(70.28 \mathrm{mg}, 0.1 \mathrm{mmol})$ in chloroform $(10 \mathrm{~mL})$ and $\mathrm{Ni}(\mathrm{OAc})_{2} \cdot 4 \mathrm{H}_{2} \mathrm{O}(111.98 \mathrm{mg}, 0.45 \mathrm{mmol})$ in methanol $(10 \mathrm{~mL})$ was stirred at $70{ }^{\circ} \mathrm{C}$ for $6 \mathrm{~h}$. After completion of metalation as indicated by TLC, solvent was removed under vacuum and the solid was washed with water and dried. Then the residue was purified by column chromatography (silica gel 60-120 mesh, $\mathrm{CHCl}_{3}$ : pet ether $=5: 5$ ) to afford red coloured solid compound 2b; yield: $64.55 \mathrm{mg}, 85 \%$.

UV-Visible $\left(\lambda_{\max }\right): 415,515.50,549.50,590,645.50 \mathrm{~nm} ; \mathbf{I R}(\mathrm{KBr}): 734.8,796.5$, 927.7, 1004.8, 1350.1, 1433, 1587.3, 1751.2, 2383.9, 3651.0, 3683.8 cm $\mathrm{cm}^{-1}$ Anal. calcd. for $\mathrm{C}_{44} \mathrm{H}_{28} \mathrm{~N}_{4} \mathrm{ONi} .4 \mathrm{H}_{2} \mathrm{O}$ : C, $69.58 \%$; H, 4.77\%; N, 7.37\% Found: C, 69.40\%; H, 4.50\%; $\mathrm{N}, 7.23 \%$. 
Synthesis of [5-[(3-hydroxy) phenyl)]-10,15,20-tris(phenyl)porphyrinato]copper(II) complex $\left(\mathrm{CuL}^{2}\right)(\mathbf{2 c})$

A mixture of porphyrin (2) $(70.28 \mathrm{mg}, 0.1 \mathrm{mmol})$ in chloroform $(10 \mathrm{~mL})$ and $\mathrm{Cu}(\mathrm{OAc})_{2} \cdot \mathrm{H}_{2} \mathrm{O}$ $(25.95 \mathrm{mg}, 0.13 \mathrm{mmol})$ in methanol $(5 \mathrm{~mL})$ was stirred at $60{ }^{\circ} \mathrm{C}$ for $1 \mathrm{~h}$. After completion of metalation as indicated by TLC, (silica gel 60-120 mesh, chloroform: pet ether $=6: 4$ ). The solvent was evaporated. The residue was extracted with chloroform and the organic layer was dried over anhydrous $\mathrm{Na}_{2} \mathrm{SO}_{4}$. After evaporation of solvent under reduced pressure furnished red solid compound 2c; yield: $61.14 \mathrm{mg}, 80 \%$.

UV-Visible $\left(\lambda_{\max }\right): 237,412.50,539 \mathrm{~nm}$; IR(KBr) : 746.4, 792.7, 939.3, 1128.3, 1002.9, 1144.3, 1170.7, 1282.6, 1442.7, 1596.9, 2925.8, 3382.9, $3531.4 \mathrm{~cm}^{-1} ;{ }^{1} \mathbf{H}$ NMR $(300 \mathrm{MHz}$, $\left.\mathrm{CDCl}_{3}\right): 1.25-1.57$ (br s, $-\mathrm{OH}$, of $\left.\mathrm{H}_{2} \mathrm{O}\right), 5.05(\mathrm{~s}, 1 \mathrm{H}, \mathrm{OH}) 7.25-7.95(\mathrm{~m}, 15 \mathrm{H}, \mathrm{Ar}-\mathrm{H}), 7.92$ $(\mathrm{m}, 4 \mathrm{H}, \mathrm{Ar}-\mathrm{H}) 8.95\left(\mathrm{~m}, 8 \mathrm{H}\right.$, pyrrole-H) Anal. calcd. for $\mathrm{C}_{44} \mathrm{H}_{28} \mathrm{~N}_{4} \mathrm{OCu} .4 \mathrm{H}_{2} \mathrm{O}: \mathrm{C}, 69.14 \% ; \mathrm{H}$, $4.74 \%$; N, 7.33\% Found: C, 69.0\%; H, 4.32\%; N, 7.10\%.

Synthesis of [5-[(3-hydroxy) phenyl)]-10,15,20-tris(phenyl)porphyrinato]zinc(II) complex $\left(\mathrm{ZnL}^{2}\right)(\mathbf{2 d})$

A mixture of porphyrin (2) $(70.28 \mathrm{mg}, 0.1 \mathrm{mmol})$ in chloroform $(10 \mathrm{~mL})$ and $\mathrm{Zn}(\mathrm{OAc})_{2} \cdot 2 \mathrm{H}_{2} \mathrm{O}$ $(21.95 \mathrm{mg}, 0.1 \mathrm{mmol})$ in methanol $(5 \mathrm{~mL})$ was stirred at room temperature for $30 \mathrm{~min}$. After completion of metalation as indicated by TLC (silica gel 60-120 mesh, chloroform: pet ether = 6:4). The solvent was removed under reduced pressure, residue was washed with water and it was extracted with chloroform. The organic layer was dried over anhydrous $\mathrm{Na}_{2} \mathrm{SO}_{4}$ and after evaporation of solvent afforded purple solid compound $\mathbf{2 d}$; yield: $68.9 \mathrm{mg}, 90 \%$.

UV-Visible $\left(\lambda_{\max }\right): 241,311.50,353,423,553,594,849 \mathrm{~nm}$; IR(KBr): 704.0, 752.2, 795.5, 939.3, 1001.0, 1068.5, 1174.6, 1338.5, 1452.3, 1537.2, 1595.0, 2850.6, 2918.1, $3409.9 \mathrm{~cm}^{-1}$; Far IR : 187.7, 236.7, 279.5, 399.3, 429.6, 467.0, 530.0 cm-1; ${ }^{1}$ H-NMR (300 $\mathrm{MHz}, \mathrm{CDCl}_{3}$ ): 0.85-1.60 ( br s, $-\mathrm{OH}$ of $\mathrm{H}_{2} \mathrm{O}$ ), 5.2 (s, $\left.1 \mathrm{H}, \mathrm{OH}\right) 7.2-7.75$ (m, 15H, Ar-H), 8.25 $(\mathrm{m}, 4 \mathrm{H}, \mathrm{Ar}-\mathrm{H}), 9.0\left(\mathrm{~m}, 8 \mathrm{H}\right.$, pyrrole-H) Anal. calcd. for $\mathrm{C}_{44} \mathrm{H}_{28} \mathrm{~N}_{4} \mathrm{OZn} .4 \mathrm{H}_{2} \mathrm{O}: \mathrm{C}, 68.97 \%$; $\mathrm{H}$, $4.73 \%$; N, 7.31\% Found:C, 68.72\%; H, 4.33\%; N, 7.21\%.

Synthesis of [5-[(3-hydroxy)phenyl)]-10,15,20-tris(4-chlorophenyl)porphyrinato] cobalt(II) complex $\left(\mathrm{CoL}^{3}\right)(\mathbf{3 a})$

A mixture of porphyrin (3) $(80.6289 \mathrm{mg}, 0.1 \mathrm{mmol})$ in chloroform $(10 \mathrm{~mL})$ and $\mathrm{Co}(\mathrm{OAc})_{2} \cdot 4 \mathrm{H}_{2} \mathrm{O}(62.2725 \mathrm{mg}, 0.25 \mathrm{mmol})$ in methanol $(10 \mathrm{~mL})$ was stirred at room temperature for $3 \mathrm{~h}$. After completion of metalation as indicated by TLC, the solvent was evaporated, residue washed with water, extracted with chloroform and organic layer was dried over anhydrous $\mathrm{Na}_{2} \mathrm{SO}_{4}$. After evaporation of solvent under reduced pressure furnished orange red solid compound 3a; Yield: $77.68 \mathrm{mg}$, $90 \%$.

UV-Visible $\left(\lambda_{\max }\right): 412,525,587,649 \mathrm{~nm}$; IR(KBr): 719.4, 800.4, 937.3, 1004.8, 1089.7, 1176.5, 1282.6, 1350.1, 1442.7, 1485.1, 1566.1, 2852.5, 2923.9, 3685.7, $3749.4 \mathrm{~cm}^{-1}$; Far IR: 115.5, 151.9, 250.7, 302.8 $\mathrm{cm}^{-1}$; ${ }^{1} \mathbf{H}-\mathbf{N M R}\left(300 \mathrm{MHz}, \mathrm{CDCl}_{3}\right): 0.9-1.54$ (br s, OH of $\left.\mathrm{H}_{2} \mathrm{O}\right), 5.10$ (s, $1 \mathrm{H}, \mathrm{OH}), 6.8-8.0(\mathrm{~m}, 12 \mathrm{H}, \mathrm{Ar}-\mathrm{H}), 8.7(\mathrm{~m}, 4 \mathrm{H}, \mathrm{Ar}-\mathrm{H}), 9.1(\mathrm{~m}, 8 \mathrm{H}$, pyrrole-H) Anal. calcd. for $\mathrm{C}_{45} \mathrm{H}_{25} \mathrm{~N}_{4} \mathrm{OCl}_{3} \mathrm{Co} .4 \mathrm{H}_{2} \mathrm{O}$ : C, 61.22\%; H, 3.85\%; N, 6.49\% Found : C, 61.0\%; H, 3.62\%; N, $6.37 \%$. Synthesis of [5-[(3-hydroxy)phenyl)]-10,15,20 tris-(4-chlorophenyl)porphyrinato] nickel(II) complex $\left(\mathrm{NiL}^{3}\right) \mathbf{( 3 b )}$

A mixture of porphyrin (3) $(80.6289 \mathrm{mg}, 0.1 \mathrm{mmol})$ in chloroform $(10 \mathrm{~mL})$ and $\mathrm{Ni}(\mathrm{OAc})_{2} \cdot \mathrm{H}_{2} \mathrm{O}(124.45 \mathrm{mg}, 0.5 \mathrm{mmol})$ in methanol $(10 \mathrm{~mL})$ was stirred at $60{ }^{\circ} \mathrm{C}$ for $5 \mathrm{~h}$. 
After completion of metalation as indicated by TLC, the solvent was removed under reduced pressure. The residue was washed with water to remove excess metal acetate and it was extracted with chloroform, organic layer, dried over anhydrous $\mathrm{Na}_{2} \mathrm{SO}_{4}$ and removal of solvent under vacuum afforded crude product which was purified by column chromatography (silica gel 60-120 mesh, $\mathrm{CHCl}_{3}$ : pet ether $=5: 5$ ). The second band was collected and after evaporation of solvent afforded red solid compound $\mathbf{3 b}$; yield: 63.03 $\mathrm{mg}, 80 \%$.

UV-Visible $\left(\lambda_{\max }\right): 413.50,518.0,547.50,589.50,647.00 \mathrm{~nm} ; \mathbf{I R}(\mathbf{K B r}): 680.8$, 798.5, 1008.7, 1089.7, 1176.5, 1350, 1423.4, 1560.3, 2370.4, 2923.9, 3681.9, $3755.1 \mathrm{~cm}^{-}$ ${ }^{1}$; ${ }^{1} \mathbf{H}-\mathbf{N M R}\left(300 \mathrm{MHz}, \mathrm{CDCl}_{3}\right): 0.9-1.58$ ( br s, -OH of $\left.\mathrm{H}_{2} \mathrm{O}\right), 5.20(\mathrm{~s}, 1 \mathrm{H}, \mathrm{OH}), 7.2-$ $8.1(\mathrm{~m}, 12 \mathrm{H}, \mathrm{Ar}-\mathrm{H}), 8.7(\mathrm{~m}, 4 \mathrm{H}, \mathrm{Ar}-\mathrm{H}), 8.80(\mathrm{~m}, 8 \mathrm{H}$, pyrrole-H) Anal. calcd. for: $\mathrm{C}_{44} \mathrm{H}_{25} \mathrm{~N}_{4} \mathrm{OCl}_{3} \mathrm{Ni} .4 \mathrm{H}_{2} \mathrm{O}: \mathrm{C}, 61.23 \% ; \mathrm{H}, 3.85 \%$; N, 6.49\% Found : C, 61.0\%; H, 3.49\%; $\mathrm{N}, 6.09 \%$.

Synthesis of [5-[(3-hydroxy)phenyl)]-10,15,20 tris-(4-chlorophenyl)porphyrinato] copper(II) complex $\left(\mathrm{CuL}^{3}\right)(\mathbf{3 c})$

A mixture of porphyrin (3) $(80.62 \mathrm{mg}, 0.1 \mathrm{mmol})$ in chloroform $(8 \mathrm{~mL})$ and $\mathrm{Cu}(\mathrm{OAc})_{2} \cdot \mathrm{H}_{2} \mathrm{O}$ (37.35 mg, $0.15 \mathrm{mmol})$ in methanol $(5 \mathrm{~mL})$ was stirred at room temperature for $10 \mathrm{~min}$. After completion of metalation as indicated by TLC (silica gel 60-120 mesh, chloroform: pet ether $=5: 5$, one drop of methonol). The solvent was evaporated, the residue was extracted with chloroform and the organic phase was dried over anhydrous $\mathrm{Na}_{2} \mathrm{SO}_{4}$. After evaporation of solvent furnished red solid compound 3c; Yield: $64.49 \mathrm{mg}, 80 \%$.

UV-Visible $\left(\lambda_{\max }\right): 235,416,539.50 \mathrm{~nm}$; IR(KBr): 717.5, 800.4, 939.3, 1002.9, 1089.7, 1174.6, 1344.3, 1444.6, 1487.0, 1602.7, 1845.7, 2337.6, 2368.4, 3649.1, 3681.9 $\mathrm{cm}^{-1}$; Far IR : 227.4, 248.4, 281.0, $302.8 \mathrm{~cm}^{-1}$; Mass (TOF MSES + 339) $\mathrm{m} / \mathrm{z}: 795.3064\left(\mathrm{M}^{+}\right) ;{ }^{1} \mathbf{H}$ NMR $\left(300 \mathrm{MHz}, \mathrm{CDCl}_{3}\right): 0.8-1.58$ (br s, $-\mathrm{OH}$ of $\left.\mathrm{H}_{2} \mathrm{O}\right), 5.10(\mathrm{~s}, 1 \mathrm{H}, \mathrm{OH}), 7.14-7.86(\mathrm{~m}, 12 \mathrm{H}, \mathrm{Ar}-\mathrm{H})$, $8.4(\mathrm{~m}, 4 \mathrm{H}, \mathrm{Ar}-\mathrm{H}), 8.85(\mathrm{~m}, 8 \mathrm{H}$, pyrrole $-\mathrm{H})$ Anal. calcd. for: $\mathrm{C}_{44} \mathrm{H}_{25} \mathrm{~N}_{4} \mathrm{OCl}_{3} \mathrm{Cu} .4 \mathrm{H}_{2} \mathrm{O}: \mathrm{C}$, $60.89 \%$; H, 3.83\%; N, 6.45\% Found: C, 60.58\%; H, 3.49\%; N, 6.30\%.

Synthesis of [5-[(3-hydroxy)phenyl)]-10,15,20 tris-(4-chlorophenyl)porphyrinato] zinc(II) complex $\left(\mathbf{Z n L}^{3}\right)(3 d)$

A mixture of porphyrin (3) $(120 \mathrm{mg}, 0.15 \mathrm{mmol})$ in chloroform $(8 \mathrm{~mL})$ and $\mathrm{Zn}(\mathrm{OAc})_{2} \cdot 2 \mathrm{H}_{2} \mathrm{O}$ $(65.85 \mathrm{mg}, 0.3 \mathrm{mmol})$ in methanol $(5 \mathrm{~mL})$ was stirred at room temperature for $10 \mathrm{~min}$. After completion of metalation as indicated by TLC (silica gel 60-120 mesh, chloroform: pet ether $=6: 4$, one drop of methanol).

The solvent was evaporated, the residue was extracted with chloroform. The organic layer was dried over anhydrous $\mathrm{Na}_{2} \mathrm{SO}_{4}$ and after evaporation of solvent under reduced pressure furnished purple solid compound 3d; yield: $116.0 \mathrm{mg}, 90 \%$.

UV-Visible $\left(\lambda_{\max }\right): 227.50,313.50,422,554.50 \mathrm{~nm}$; IR(KBr): 717.5, 800.4, 939.3, 1002.9, 1089.7, 1174.6, 1284.5, 1338.5, 1483, 1583.4, 2933.5 $\mathrm{cm}^{-1} ;{ }^{1} \mathbf{H}$ NMR $(300 \mathrm{MHz}$, $\left.\mathrm{CDCl}_{3}\right): 1.25-1.53\left(\right.$ br s, $-\mathrm{OH}$ of $\left.\mathrm{H}_{2} \mathrm{O}\right), 5.2(\mathrm{~s}, 1 \mathrm{H}, \mathrm{OH}), 7.2-7.80(\mathrm{~m}, 12 \mathrm{H}, \mathrm{Ar}-\mathrm{H}), 8.4(\mathrm{~m}$, $4 \mathrm{H}, \mathrm{Ar}-\mathrm{H}), 8.9(\mathrm{~m}, 8 \mathrm{H}$, pyrrole $-\mathrm{H})$ Anal calcd for : $\mathrm{C}_{44} \mathrm{H}_{25} \mathrm{~N}_{4} \mathrm{OCl}_{3} \mathrm{Zn} .4 \mathrm{H}_{2} \mathrm{O}: \mathrm{C}, 60.77 \% ; \mathrm{H}$, $3.82 \%$; N, 6.44\% Found : C, 60.69\%; H, 3.50\%; N, 6.21\%.

\section{Results and Discussion}

The ligands (1-3) were prepared by modified Adler method published elesware ${ }^{14}$ following reaction (c.f.Scheme 1). 
When the ligand and different metalacetates in (chloroform-methanol) allowed to react, the corresponding metal complexes was formed (c.f.Scheme 2).

\section{UV-Visible spectra}

Metalloporphyrins can be divided into two groups based on their UV-Visible and fluorescence properties. Regular metalloporphyrins contain closed shell metal ions $\left(\mathrm{d}^{0}\right.$ or $\mathrm{d}^{10}$ ) for example $\mathrm{Zn}(\mathrm{II})$, in which the $\mathrm{d} \pi(\mathrm{dxz}$, dyz) metal based orbitals are relatively low in energy. These have very little effect on the porphyrin $\pi$ to $\pi^{*}$ energy gap in the porphyrin electronic spectra. Hypsoporphyrins, are metalloporphyrins in which the metals are of $\mathrm{d}^{\mathrm{m}}$, $\mathrm{m}=6-9$, having filled $\mathrm{d} \pi$ orbitals. In Hypsoporphyrins, there is a significant metal $\mathrm{d} \pi$ to porphyrin $\pi^{*}$ orbital interaction (metal to ligand $\pi$ back bonding). These results in an increased porphyrin $\pi$ to $\pi^{*}$ energy separation causing the electronic absorption to undergo hypsochromic blue shift. The UV-Visible spectral data for these complexes and ligands are listed in Table 1.

Table 1. UV-Visible spectral data of compound (1-3) and (1a-1d, 2a-2d and 3a-3d) in chloroform

\begin{tabular}{ccccc}
\hline \multirow{2}{*}{$\begin{array}{c}\text { S. } \\
\text { No. }\end{array}$} & Porphyrins/ & Compound & \multicolumn{2}{c}{ UV-Visible parameters, $\lambda_{\max } / \mathrm{nm}$} \\
\cline { 4 - 5 } \cline { 4 - 4 } 1 & metalloporphyrins & No. & Soret & Q-bands \\
2 & $\mathrm{H}_{2} \mathrm{~L}^{1}$ & $\mathbf{1}$ & 416 & $516,551,590,646$ \\
3 & $\mathrm{CoL}^{1}$ & $\mathbf{1 a}$ & 412 & 528 \\
4 & $\mathrm{NiL}^{1}$ & $\mathbf{1 b}$ & 410.50 & $522,590,649$ \\
5 & $\mathrm{CuL}^{1}$ & $\mathbf{1 c}$ & 413 & $540,574,617$ \\
6 & $\mathrm{Zn} \mathrm{L}^{1}$ & $\mathbf{1 d}$ & 416 & $553,595,621,771.50$ \\
7 & $\mathrm{H}_{2} \mathrm{~L}^{2}$ & $\mathbf{2}$ & 410 & $515,550,589,646$ \\
8 & $\mathrm{Co} \mathrm{L}^{2}$ & $\mathbf{2 a}$ & 410.50 & 528.50 \\
9 & $\mathrm{Ni} \mathrm{L}^{2}$ & $\mathbf{2 b}$ & 415 & $515.50,549.50,590,645.50$ \\
10 & $\mathrm{CuL}^{2}$ & $\mathbf{2 c}$ & 412.50 & 539.0 \\
11 & $\mathrm{Zn} \mathrm{L}^{2}$ & $\mathbf{2 d}$ & 423 & $533,594,849$ \\
12 & $\mathrm{H}_{2} \mathrm{~L}^{3}$ & $\mathbf{3}$ & 412 & $515,550.50,590,646.50$ \\
13 & $\mathrm{Co} \mathrm{L}^{3}$ & $\mathbf{3 a}$ & 412 & $525,587,649$ \\
14 & $\mathrm{Ni} \mathrm{L}^{3}$ & $\mathbf{3 b}$ & 413.50 & $518,547.50,589.50,647.0$ \\
15 & $\mathrm{Cu} \mathrm{L}^{3}$ & $\mathbf{3 c}$ & 416.0 & 539.50 \\
\hline
\end{tabular}

The absorption spectra of compounds (1a-1d, 2a-2d and 3a-3d), indicate that upon metallation the porphyrin ring deprotonates forming a dianionic ligand. The metal behaves as Lewis acid, accepting lone pairs of electrons from dianionic porphyrin ligand. From spectra of all ligands and complexes, the band around $400 \mathrm{~nm}$ which is Soret band and has high extinction coefficient and generally four lower extinction bands are Q-bands.

All synthesized complexes are highly coloured and show fluorescence. Unlike most transition metal complexes, the colour is due to absorption(s) within the porphyrin ligand involving the excitation of electrons from $\pi$ to $\pi^{*}$ porphyrin ring orbital ${ }^{15}$. When metal binds to porphyrin absorption spectrum changes owing to symmetry effects, but the $\pi$ to $\pi^{*}$ energygap little affected and regular metalloporphyrin spectrum resulted. The hypsochromic shift and loss of fluorescence are distinct characteristics of hypsoporphyrins ${ }^{15}$. The absorption indicates that change in spectrum (fewer peaks) on metallation is due to increased symmetry relation to free 
base porphyrin. It has been established that the central metal ion ${ }^{16}$ and substituent at meso positions ${ }^{17-20}$ affect the optical spectra of porphyrin which will decrease in the energy transition (red shift and change in oscillator strength of the absorption band).

When zinc binds to free base porphyrin, absorption spectrum changes owing to symmetry effect but $\pi$ to $\pi^{*}$ energy gap is little affected and a regular metalloporphyrin spectrum resulted. In contrast to the other metals (for example $\mathrm{Ni}$, $\mathrm{Co}$ and $\mathrm{Cu}$ ) peaks are shifted to shorter wavelength due to metal $\mathrm{d} \pi$ (dxz and dyz) to porphyrin $\pi^{*}$ bonding. In all complexes $\in$ values of the metal derivatives is about $25-50 \%$ as compared to corresponding free base porphyrin.

\section{IR spectra}

The IR spectral data of porphyrins and corresponding metalloporphyrins ascertain some functional groups to exist. The $v_{\mathrm{N}-\mathrm{H}}$ absorption band of free base porphyrin is at about $3320 \mathrm{~cm}^{-1}, \delta_{\mathrm{N}-\mathrm{H}}$ (in planarity) and $\delta_{\mathrm{N}-\mathrm{H}}$ (out of planarity) absorption bands are about $927 \mathrm{~cm}^{-1}$ and $728 \mathrm{~cm}^{-1} \cdot v_{\mathrm{C}-\mathrm{H}}$ absorption band of porphyrin is about $2920 \mathrm{~cm}^{-1}$. Some peaks appearing in the range of 980 to $710 \mathrm{~cm}^{-1}$ are related to skeletal ring vibrations of free base porphyrin. These bands disappeared in all metalloporphyrins after metal insertion reaction, and new strong band appears near $1000 \mathrm{~cm}^{-1}$ corresponding to skeletal ring vibration of metal porphyrin reconcile the result of literature ${ }^{21-23}$. The Far IR spectra of metalloporphyrins show $\mathrm{V}_{\mathrm{M}-\mathrm{N}}$ stretching vibration which support the complexation.

\section{Mass spectra}

Mass spectra of metalloporphyrins shows molecular ion peak which confirms formation of title compound.

\section{${ }^{1} H N M R$}

The ${ }^{1} \mathrm{H}-\mathrm{NMR}$ data of free base porphyrins (1-3) and metalloporphyrins show that the peak at around $-2.9 \mathrm{ppm}$ is the more shielded $\mathrm{N}-\mathrm{H}$ proton at the center of porphyrin ligands. This peak disappears after complexation of porphyrin with metal because two $\mathrm{H}$ atom are replaced by metal ion ${ }^{22}$. There is great movement to high field on the basis of strong shield effect of porphyrin ring.

\section{Electron spin resonance study}

A large number of investigations working on porphyrins and related systems have utilized this method in probing into the structural and dynamic aspects of porphyrins as well as their role in biological systems ${ }^{13}$. In case of paramagnetic porphyrin system one or more unpaired electrons may reside either on $\pi$ ligand system or in central metal atom or in both.

In order to obtain information of geometry, the X-band EPR spectra of few complexes have been recorded in the powder state at LNT. The values of g-Tensor are depicted in Table 2. The $g_{\|}$and $g_{\perp}$ values for compound (1c) and (3c) leads to $D_{4} h$ symmetry of compound (square planar) around $\mathrm{Cu}(\mathrm{II})$ ion.

The splitting of spectra into four lines at LNT confirms the ground state of $\mathrm{Cu}(\mathrm{II})$ ion as $\mathrm{S}=1 / 2$. The unpaired electron of the metal ion interacts with $\mathrm{Cu}$ (II) nucleus with the nuclear spin $I=3 / 2$ resulting in the splitting of spectrum into four lines. This confirms that copper is in +2 oxidation state with $S=1 / 2$ as a spin state resulting in the single line main EPR spectra.

Moreover, the values of $G$ calculated as $g_{\|}-2 / g_{\perp}-2$ comes out to $>4$ for both compounds which leads to the packing of molecular planes one above the other confirms the planar arrangement of porphyrin rings in three dimensional space. 
Microwave Frequency:9.762770 GHz; Microwave Power:4 mW; Modulation Frequency:100 kHz; Receiver Gain:5.02×10

Table 2. ESR spectral data for compound (1c and 3c) at LNT

\begin{tabular}{ccccccc}
\hline S. No. & Compound No. & $\mathrm{g}_{1}$ & $\mathrm{~g}_{2}$ & $\mathrm{~g}_{3}$ & $\mathrm{~g}_{4}$ & $\mathrm{~g}_{5}$ \\
\hline 1 & 1c & 2.39 & 2.22 & 2.05 & 1.97 & - \\
2 & 3c & 2.42 & 2.24 & 2.05 & 2.001 & - \\
\hline
\end{tabular}

\section{Fluorescence study}

Fluorescence spectra of $\mathrm{Zn}$ metalloporphyrins (1d and 3d) were studied. The excitation spectra of fluorescence are in good agreement with absorption spectra. This implies that the fluorescence does not originate from some impurities. The excitation was carried out in visible range. These two complexes show fluorescence behavior.

Table 3. Excitation and emission spectral data of compound (1d)

\begin{tabular}{cc}
\hline Emission spectra(in $\left.\mathrm{CHCl}_{3}\right)$ & Excitation spectra in $\mathrm{CHCl}_{3}$ \\
\hline$\lambda \mathrm{ex}=566.0 \mathrm{~nm}$ & $\lambda \mathrm{ex}=604.0 \mathrm{~nm}$ \\
$\lambda \mathrm{em}=607.0 \mathrm{~nm}$ & $\lambda \mathrm{em}=607.0 \mathrm{~nm}$ \\
\hline
\end{tabular}

The emission spectrum of compound 1d show only one peak at 607.0 while the excitation spectrum show four peaks at 386.0, 438.0, 566.0 and $604.0 \mathrm{~nm}$.

Table 4. Excitation and emission spectral data of compound (3d)

\begin{tabular}{cc}
\hline Emission spectra(in $\mathrm{CHCl}_{3}$ ) & Excitation spectra in $\mathrm{CHCl}_{3}$ \\
\hline$\lambda \mathrm{ex}=563.0 \mathrm{~nm}$ & $\lambda \mathrm{ex}=563.0 \mathrm{~nm}$ \\
$\lambda \mathrm{em}=605.0 \mathrm{~nm}$ & $\lambda \mathrm{em}=605.0 \mathrm{~nm}$ \\
\hline
\end{tabular}

The emission spectra of compound 3d show peaks at 605.0, 651.0 and $817.0 \mathrm{~nm}$ while excitation spectra show four peaks at 360.0, 393.0, 439.0 and $563.0 \mathrm{~nm}$.

\section{Magnetic study}

The Faraday technique is more useful for porphyrin study where only limited amount of sample is available ${ }^{13}$. Many workers determine metalloporphyrins susceptibilities in solution by the Evan ${ }^{24}$, by the use of small amount of sample.

Magnetic susceptibility $\left(\chi_{\mathrm{m}}\right)$ measurements were performed on Faraday balance "CHAN 2000 (model $1 \mathrm{NC}$ CERPITAS, CA,USA) Using $\mathrm{Hg}\left[\mathrm{Co}(\mathrm{CNS})_{4}\right], \chi_{\mathrm{g}}=16.44 \times 10^{-6} \mathrm{~g} / \mathrm{Ml}$ (at $28^{\circ} \mathrm{C}$ ) as the calibrating agent at room temperature.Molar susceptibility value were calculated by using following formula provided with instrument.

$$
x_{m}=\frac{16.44 x \Delta W x S x M x 10^{-6}}{W x \Delta S}(\text { Cgs unit })
$$

Where $\mathrm{W}=$ Weight of sample, $\mathrm{S}=$ Weight of Sample, $\Delta \mathrm{W}$ and $\Delta \mathrm{S}=$ Change in weights of sample and standard respectively, on application of magnetic field. $M=$ Molecular weight of the sample. Effective magnetic moment calculated (Table 5) by using formula $\mu 2.84 \sqrt{ } \chi \mathrm{m} \times \mathrm{T}$

Table 5. Effective magnetic moment for compound (1a,1c,3c)

\begin{tabular}{ccc}
\hline S.No. & Compoud No. & $\begin{array}{c}\text { Magnetic moment } \\
\mu \text { (eff.) (B. M.) }\end{array}$ \\
\hline 1 & 1a & 2.81 \\
2 & 1c & 1.89 \\
3 & 3c & 1.94 \\
\hline
\end{tabular}




\section{Acknowledgement}

P.B. Gujarathi thanks University Grants Commission, New Delhi for teacher fellowship under faculty improvement programme and university of Pune, IIT Bombay for spectral analysis.

\section{References}

1. Kadish K M, Smith K M and Guilard R, Eds. The Porphyrin Handbook Academic Press: New York 2000, vol. 1-10.

2. Dolphin D, Ed., The Porphyrins, Academic Press: New York 1978, 1-7.

3. Reed C A and Momenteau M, Chem Rev., 1994, 94(3), 659-698; DOI:10.1021/cr00027a006

4. Chou J H, Kosal M F, Nalwa H S, Rakow N A and Suslick K S, In The Porphyrin Handbook Eds., Kadish K M, Smith K M and Guilard R, Academic Press: New York, 2000, 6, 43.

5. Ravikanth M and Chandrasheka T K, Struct Bonding, Berlin, 1995, 82, 1.

6. Shelnutt J A, Song X Z, Ma J G, Jia S L, Jentzen W and Medforth C J, Chem Soc Rev., 1998, 27, 31-42; DOI:10.1039/A827031Z

7. Kosal M E, Chou J H, Wilson S R and Suslick K S, Nature Mater., 2002, 1, 118; DOI:10.1038/nmat730

8. Egger N G, Motamedi M, Pow-Sang M, Orihuela E and Anderson K E, Parmacology 1996, 52(6), 362-370; DOI:10.1159/000139403

9. Nakjima S, Sokaka I and Takemura T J, Drug Delivery System., 1996, 11(2), 105110; DOI:10.2745/dds.11.105

10. Winkelman J, Rubenfeld S and Mcafee J, J Nuclear Medicine, 1964, 5, 462-470.

11. Sanders J K M, In The Porphyrin Handbook Kadish K M, Smith K M and Guilard R, Ed., Academic Press : New York, 2000, 3, 347.

12. Takahashi $\mathrm{R}$ and Kokube Y, J Am Chem Soc., 2003, 125, 2372-2373; DOI:10.1021/ja028325y and references cited therein.

13. Smith K M, Porphyrins and Metallorporphyrins, Elsevier Scientific Publishing Co. Amsterdam, The Netherlands, 1975, Chap. 12, p. 454.

14. Adler A D, Longo F R, Finarelli F C, Assour J and Korsakoff L, J Org Chem., 1967, 32(2), 476; DOI:10.1021/jo01288a053

15. Marsh D F and Mink L M, J Chem Educ., 1996, 73, 1188-1190; DOI:10.1021/ed073p1188

16. Gouterman M, J Chem Phy., 1959, 30, 1139; DOI:10.1063/1.1730148

17. Moet-Ner M and Adler A D, J Am Chem Soc., 1975, 97(18), 5107-5111; DOI:10.1021/ja00851a014

18. Dalton J, Milgrom L R and Pemberton S M, J Chem Soc., Perkin Trans 2, 1980, 320.

19. Cowan J A and Sanders J K M, J Chem Soc., Perkin Trans 1, 1987, 2395-2402; http://dx.doi.org/10.1039/P19870002395

20. Wu G Z, Gan W X and Leung K H, J Chem Soc Faraday Trans., 1991, 87(18) 2933-2937; DOI:10.1039/FT9918702933

21. Thomas D W and Arthur E Martell, J Am Chem Soc., 1959, 81(19), 5111-5119; DOI:10.1021/ja01528a024

22. He Y F Wei D B and Chen H, Synth Commun., 1998, 28(15), 2843-2849; DOI:10.1080/00397919808004861

23. Liu S Q, Sun H R, Sun Z T, Xu Ji Q and Li D M, Synth Commun., 2000, 30(11), 2009-2017; DOI:10.1081/SCC-120037913

24. Evans D F, J Chem Soc., 1959, 2003-2005. 